\title{
Perancangan Aransemen Lagu Suwe Ora Jamu dan Cublak-Cublak Suweng Ditinjau dari Perspektif Ilmu Harmoni Dasar
}

\author{
Veronica Yoni Kaestri ${ }^{1}$ \\ Program Studi S-1 Seni Musik, Fakultas Seni Pertunjukan, Institut Seni Indonesia Yogyakarta
}

\begin{abstract}
The Music Arrangement of Suwe Ora Jamu and Cublak-Cublak Suweng Songs from the Perspective of Basic Harmony Science. The musical arrangement is an arranger's creativity to express his/her ideas in a song, which does not change the original song's form. As an arranger, he/she must master the music theory, which includes rhythm, melody, and harmony. Making the music arrangement must look at who will play the music arrangement, the level of player ability, voice ambition, and characteristic nuances of the song, for example, in traditional songs. The method used was experimental and referred to qualitative research with observations at Notoyudan music studio to determine the students' ability to play the musical instruments, data collection for both the field and literature studies, and interviews with facilitators and students Notoyudan Music Studio. Suwe Ora Jamu and Cublak-Cublak Suweng are traditional children's songs from Central Java that use the pentatonic scale. This music arrangement was intended for students who took the internship course (Praktek Kerja Lapangan) as there are many requests from the public to arrange traditional songs. Music students must be ready to participate in society to make many forms of music arrangement using diatonic scales and practice making the music arrangement in pentatonic scales. This music arrangement was played in a performance by the students of the Notoyudan music studio. Basic harmony science is used to make the music arrangement and melodic variations with the creativity of musical ideas. The result of the research is a music arrangement by using the primary chords, namely I, IV and V, and is played in the A Major scale. The existence of variation in chords harmony and variation in the correct placement of the chords will produce a traditional nuanced arrangement.
\end{abstract}

Keywords: design; arrangement; harmony

\begin{abstract}
ABSTRAK
Aransemen musik merupakan suatu kreativitas seorang arranger untuk mengekspresikan ide kreatifnya yang dituangkan dalam sebuah lagu, dimana tidak mengubah bentuk lagu aslinya. Sebagai arranger harus menguasai teori musik yang didalamnya terdapat ritme, melodi dan harmoni. Pembuatan aransemen harus melihat siapakah yang akan memainkan aransemen, tingkat kemampuan pemain, ambitus suara, dan ciri khas nuansa lagu misalnya dalam lagu tradisional. Pembuatan aransemen ini merupakan suatu kreativitas musisi untuk menuangkan ide-idenya. Metode yang digunakan adalah metode eksperimen dan mengacu pada penelitian kualitatif dengan observasi ke sanggar Notoyudan untuk mengetahui kemampuan anak-anak sanggar dalam memainkan instrumen, pengumpulan data baik di lapangan maupun studi pustaka dan wawancara dengan pendidik ataupun anak-anak sanggar. Suwe Ora Jamu dan Cublak-cublak Suweng merupakan lagu tradisional permainan anak-anak berasal dari Jawa Tengah, dengan menggunakan tangga nada pentatonis. Perancangan aransemen ini ditujukan untuk mahasiswa yang sedang mengikuti mata kuliah PKL, dikarenakan di luar kampus sangat banyak permintaan masyarakat umum untuk mengaransemen lagu tradisional. Mahasiswa musik harus siap untuk terjun ke masyarakat untuk membuat aransemen dalam bentuk apapun, dengan maksud tidak hanya menggunakan tangga nada diatonis tetapi juga berlatih membuat aransemen dalam tangga nada pentatonis. Hasil dari aransemen ini dimainkan oleh anak-anak sanggar Notoyudan pada saat pementasan. Ilmu harmoni dasar dipergunakan untuk pembuatan perancangan aransemen dan variasi melodi dengan kreativitas ide musikal. Hasil penelitian adalah aransemen dengan penggunaan
\end{abstract}

\footnotetext{
Alamat korespondensi: Program Studi S-1 Seni Musik, Fakultas Seni Pertunjukan, Institut Seni Indonesia Yogyakarta, Jalan Parangtritis Km. 6.5 Yogyakarta. E-mail: yonikaestri01@gmail.com; HP.: 081903730675.
} 
akur-akur pokok yaitu I, IV dan V, dan dimainkan dalam tangga nada A Mayor. Adanya variasi akurakur harmoni dan variasi penempatan nada dari pecahan akur sesuai dalam penempatannya akan menghasilkan suatu aransemen bernuansa tradisional.

Kata kunci: perancangan; aransemen; harmoni

\section{Pendahuluan}

Ilmu Harmoni merupakan suatu cabang ilmu pengetahuan yang mempelajari tentang pembentukan akur-akur dalam musik. Pada praktiknya, nada-nada dalam akur dipecah menjadi suara Sopran, Alto, Tenor, dan Bass. Pemecahan akur dalam seperti ini umumnya digunakan dalam format paduan suara. Pada perkembangan selanjutnya ilmu harmoni dapat digunakan dalam aransemen baik aransemen vokal maupun aransemen yang berbentuk instrumen seperti ansambel, duet, trio, ataupun orkestra. Dalam penelitian ini, dilakukan perancangan aransemen lagu daerah yaitu Suwe Ora Jamu dan Cublakcublak Suweng (medley) dalam bentuk ansambel yang terdiri dari instrumen piano atau keyboard, gitar, biola, dan vokal. Ansambel adalah istilah untuk pemain alat musik atau penyanyi dalam jumlah terbatas ((Prier, 1996); (Hasibuan et al., n.d.)) Secara instrumentasi, ansambel dapat dibagi menjadi dua kategori yaitu sejenis dan campuran. Ansambel yang digunakan penelitian ini termasuk dalam kategori campuran karena terdapat beberapa instrumen dalam satu kelompok ansambel.

Penelitian ini bertujuan untuk meningkatkan kemampuan dalam membuat aransemen musik, khususnya aransemen musik dalam tangga nada slendro (do, re, mi, sol, la, do) dan pelog (do, mi, fa, sol si, do). Penelitian ini dilakukan karena pada penelitian terdahulu, dilakukan perancangan aransemen musik dengan menggunakan tangga nada diatonis. Aransemen dirancang untuk membimbing mahasiswa PKL (Praktek Kerja Lapangan). Disamping itu, perkuliahan teori musik - khususnya Mata Kuliah Harmoni patut mengimplementasikan pembuatan aransemen dalam tangga nada selain diatonis. Penelitian ini sangat penting dilakukan karena mendukung program PKL mahasiswa.
Faktanya, praktik bermusik yang ada diluar kampus menunjukkan bahwa mahasiswa tidak hanya berhadapan dengan tangga nada diatonis saja, namun juga tangga nada pentatonis seperti slendro dan pelog. Sanjaya dalam artikel berjudul Metode Lima Langkah Aransemen Musik mengemukakan kerangka kerja yang disebutnya metode lima langkah aransemen, yaitu: menentukan instrumen yang digunakan, menuliskan notasi lagu yang didalamnya terdapat ekspresi dan bentuk lagu, memodifikasi dan menciptaan ide-ide baru (pengembangan ritme, motif, ritme, harmoni, melodi dan lain sebagainya, menyusun materi yang sudah digarap (merespon ide-ide spontan) dan mengevaluasi dan merevisi hasil aransemen (Sanjaya, 2013). Dengan demikian, mahasiswa sebagai peseerta didik hendaknya menguasai teori musik secara mendalam untuk dapat membuat suatu aransemen musik.

Penelitian dalam skema terapan disini peneliti melakukan pengembangan dalam pembelajaran harmoni, mengolah nada-nada pentatonis sehingga perancangan aransemen kedua lagu tersebut menjadi sebuah aransemen dengan menggunakan teknik yang mudah diterima dan dipelajari oleh mahasiswa. Pengembangan ilmu harmoni tersebut kemudian diajarkan kepada mahasiswa untuk mempersiapkan mereka untuk masuk di dunia luar perkuliahan. Memecahkan masalah ketika mereka mendapatkan tugas membuat aransemen lagulagu daerah. Hasil dari perancangan aransemen kemudian dimainkan oleh anggota sanggar dengan melakukan pementasan ketika wabah covid 19 sudah selesai. Pembuatan perancangan aransemen lagu daerah dengan judul Suwe Ora Jamu dan Cublak-cublak Suweng selain berguna untuk mahasiswa tetapi juga dilatarbelakangi oleh permintaan dari pihak pengelola sanggar itu sendiri untuk meminta pembuatkan aransemen lagu tersebut dalam bentuk medley. 
Dikarenakan adanya wabah Covid-19, maka sumber-sumber kepustakaan yang berupa bukubuku, jurnal penelitian, artikel yang relevan dengan permasalahan penelitian ini sangat dibutuhkan untuk memecahkan masalah yang ada. Pengumpulan data baik wawancara yang sudah dilakukan pada saat sebelum wabah Covid-19 dan hasil dari studi kepustakaan kemudian disusun dalam bentuk laporan penelitian dan dapat dipertanggungjawabkan. Berdasarkan uraian latar belakang diatas maka dapat dirumuskan permasalahan sebagai berikut: 1. Bagaimanakah proses perancangan aransemen lagu Suwe Ora Jamu dan Cublak-cublak Suweng (medley) dalam bentuk ansambel yang dimainkan oleh instrumen piano atau keyboard, gitar, biola dan vokal?; 2. Dalam konteks ilmu harmoni sebagai unsur ide perancangan aransemen lagu Suwe Ora Jamu dan Cublak-cublak Suweng, apakah terdapat perbedaan antara pembuatan/penyusunan akur dalam tangga diatonis dan dalam tangga nada pentatonik?

\section{Metode Penelitian}

Metode perancangan merupakan suatu proses langkah-langkah yang ditempuh seorang peneliti untuk menemukan suatu konsep melalui ide-ide yang dilengkapi dengan sumber-sumber tertulis seperti kepustakaan, jurnal-jurnal yang relevan dengan topik yang diteliti (Mulyani, 2017). Dalam penelitian ini, munculnya ide perancangan aransemen lagu daerah Suwe Ora Jamu dan Cublak-cublak Suweng adalah keinginan penulis untuk melatih mahasiswa membuat aransemen diluar dari kebiasaan. Maksud dari kata kebiasaan adalah dalam perkuliahan harmoni sering kali membuat aransemen dalam tangga nada diatonis baik mayor maupun minor, tapi pada penelitian ini tanggganada yang digunakan adalah tangga nada pentatonis pelog dan slendro. Teknik pemecahan akur dalam harmoni dikembangkan sehingga aransemen terlihat indah, dengan tidak meninggalkan tujuan untuk siapa aransemen tersebut dibuat. Selain untuk mengajarkan kepada mahasiswa bagaimana membuat aransemen dalam tangga nada pentatonis, tetapi juga atas permintaan pihak dari sanggar untuk dibuatkan aransemen dalam bentuk medley. Pemilihan lagu dari pihak sanggar dan diperuntukkan untuk anak-anak didik sanggar dengan kemampuan dasar.

Metode yang digunakan dalam penelitian ini menggunakan metode penelitian tindakan (action research). Penelitian tindakan harus jelas membedakan perbedaan ciri tindakan dan penelitian sehingga peneliti harus bertindak langsung dan sekedar hanya menonton (Yaumi, 2016). Melihat uraian diatas peneliti terjun langsung ke sanggar sebagai pengajar yang kemudian mudah dalam melakukan observasi. Eksperimen perancangan dalam penelitian ini menggunakan pendekatan kualitatif (Gunawan, 2013), dimana observasi sudah dilakukan oleh peneliti sebelum wabah Covid-19 terjadi. Penulis sendiri merupakan pengajar tidak tetap di sanggar tersebut dan juga sebagai dosen pembimbing mahasiswa PKL di Program studi S-1 Seni Musik. Obsevasi tempat dimana penelitian tersebut akan dilaksanakan yaitu di sanggar Seni Notoyudan Yogyakarta yang beralamatkan di Jl. Notoyudan, Pringgokusuman, Gedong Tengen Yogyakarta. Proses pengumpulan data terdiri dari berapa jumlah peserta sanggar, alat musik yang dimainkan, mengukur kemampuan peserta sanggar sehingga perancangan aransemen lagu dapat disesuaikan sebagaimana mestinya. Pemilihan lagu atas permintaan sanggar dimana ketika mereka melakukan pementasan sering diminta membawakan lagu-lagu daerah/tradisonal. Pada hakekatnya musik tradisional bukanlah merupakan suatu substansi musikal akan tetapi suatu istilah yang diberikan pada suatu musik yang telah mengalami proses mentradisi ((Rumengan, 2009); (Ceunfin et al., 2019)).

Ide perancangan muncul ketika sudah melakukan observasi bertujuan untuk apa perancangan tersebut dilakukan. Ide kreatif dalam perancangan ini sangat dibutuhkan supaya hasil dari perancangan aransemen menarik (terdapat hasil yang nyata), sebagai contoh melodi tidak hanya dimainkan oleh vokal tetapi bisa dimainkan instrumen biola, variasi pola iringan maupun ritmis dan lain sebagainya. Pengumpulan datadata yang berkaitan sanggar sudah didapatkan penulis ketika wabah Covid-19 belum merebak, sedangkan data-data yang bersifat studi literatur 
akan dilaksanakan selanjutnya, sumber-sumber yang relevan diambil penulis untuk medukung ide perancangan aransemen. Fokus yang dilakukan peneliti saat ini adalah memperbanyak kepustakaan termasuk jurnal-jurnal yang diambil dari media online, hal tersebut dapat memperkaya peneliti dan dapat mewujudkan hasil penelitian yang dapat dipertanggujawabkan. Tahap selanjutnya adalah munculnya konsep, pelaksanna dan pengolahan data dan menyimpulkan hasil dari penelitian, melakukan revisi-revisi dimana menambah ataupun mengurangi bagian-bagian yang dirasa belum sesuai.

Tinjauan pustaka merupakan suatu acuan yang berupa jurnal maupun penelitian yang terdahulu, sehingga menunjukkan pengembangan penelitian yang akan dilakukan. Berikut adalah penelitian, jurnal maupun buku yang sangat berhubungan dengan penelitian yang akan dilaksanakan.

1. Penelitian/Penciptaan Terdahulu

Penelitian tentang aransemen lagu jawa sangatlah banyak, akan tetapi aransemen yang dihubungkan dengan ilmu harmoni masih belum ditemukan, maka dari itu peneliti akan menggunakan hasil penelitian peneliti sendiri tahun 2019 mengenai aransemen lagu Bagimu Negeri yang ada kaitannya dengan ilmu harmoni. Penelitian yang dilakukan peneliti saat ini bisa dikatakan merupakan pengembangan dari penelitian sebelumya. Penelitian sebelumnya menggunakan lagu dengan tangga nada diatonis, akan tetapi pada penelitian saat ini menggunakan lagu dengan tangga nada pentatonis. Tangga nada pentatonis pada saat ini diterapkan dengan pendekatan dengan kemiripan (kuasi) yaitu nada dalam pentatonis diselaraskan dengan nadanada dalam laras diatonis (Pardede \& Purba, 2021). Dengan diselaraskannya dengan tangga nada diatonis maka hal ini dapat mempermudah mahasiswa untuk membuat aransemen.

Penelitian dengan judul "Aplikasi Ilmu Harmoni Dan Ilmu Kotrapung Dasar Dalam Pembuatan Aransemen Lagu Bagimu Negeri Di FSP Jurusan Musik ISI Yogyakarta” penelitian 29 November 2019. Penelitian ini sudah masuk dalam jurnal Promusika tetapi masih dalam proses penerbitan. Dalam penelitian ini menggunakan pendekatan musikologi digunakan penulis untuk membedah bagaimana mahasiswa mengaransemen lagu dengan kedua mata kuliah tersebut, yang pada akhirnya akan muncul beberapa aransemen dari mahasiswa yang kemudian diambil salah satu untuk dijadikan hasil dari penelitian. Penulis menggunakan juga metode eksperimen dimana mahasiswa harus membuat aransemen dengan menggunakan ilmu harmoni dan Ilmu Kontrapung, secara berkelompok yang kemudian langsung diterapkan. Hasil dari aransemen mahasiswa yang dimasukkan dalam penelitian ini adalah berupa satu karya dengan menggunakan salah satu ilmu tersebut dan yang kedua adalah menggabungkan keduanya. Tujuan dari penelitian ini adalah diharapkan mahasiswa aktif dan mampu mengaplikasikan Ilmu Harmoni Dasar dan Ilmu Kontrapung Dasar dalam bentuk aransemen lagu Bagimu Negeri.

Penelitian dengan judul "Aransemen Lagu Daerah Indonesia untuk ansambel Gitar Sebagai Peningkatan Strategi Peningkatan Kualitas Pembelajaran Mata Kuliah Ansambel Gitar Di Jurusan Musik FSP Yogyakarta", penelitian tahun 2018 Penelitian ini membahas tentang aransemen lagu Gundul-gundul Pacul dalam bentuk ansambel juga tetapi dimainkan oleh mahasiswa dalam bentuk ansambel gitar. Perbedaan dengan penelitian saat ini adalah aransemen lagu berbentuk medley untuk ansambel (piano/keyboard, gitar, biola dan vokal) dan ditujukan untuk peserta sanggar. Perencanaan aransemen ini dibedah dengan ilmu Harmoni dengan tujuan bisa digunakan atau diajarkan mahasiwa dalam perkuliahan maupun dalam PKL.

Buku musik dengan judul 'lagu daerah" oleh Siti Rochani Buku ini berisi lagu daerah. Peneliti sudah mencari beberapa buku musik dan kebanyakan dari buku musik hanya berupa melodi, akur dan syair. Maka dari itu dapat dikatakan bahwa penelitian yang akan dilakukan bersifat original karena belum ada buku ataupun penelitian yang membuat perancangan aransemen yang dibedah dengan 
ilmu harmoni dan ditujukan pada sanggar, dimana memerlukan ketelitian yang sangat jeli dengan melihat kemampuan peserta sanggar (Rochani, 2012). Jurnal yang relevan dalam penelitian ini oleh berjudul R.M Singgih Sanjaya dalam judul "Lima Langkah Aransemen Musik". Jurnal ini membahas pendekatan metodologis dalam aransemen musik berdasarkan penelitian dan pengalaman. Terdapat lima langkah dalam aransemen musik, yaitu: konsep aransemen, aransemen awal, menciptakan ide-ide baru, aransemen lanjut dan evaluasi dan revisi (Sanjaya, 2013). Jurnal ini sangat membantu penulis dalam perancangan aransemen yang akan dibuat.

Jurnal yang relevan digunakan untuk mendukung penelitian ini berjudul "Kreatifitas Dalam Pembuatan Aransemen Musik Sekolah" oleh Heni Kusumawati (Kusumawati, 2016). Jurnal ini Kreativitas sarana untuk mengungkapkan ekspresi, imajinasi dan apresiasi dalam bermusik. Salah satu kegiatan pembelajaran seni budaya/seni musik adalah mengekspresikan diri melalui karya seni dengan pembuatan aransemen musik. Aransemen merupakan kegiatan kreatif dalam mengolah dan mengembangkan elemen-elemen musik menjadi sebuah karya baru. Aransemen merupakan pengadaptasian satu medium musik yang asli menjadi medium yang berbeda ((Scholes, 1983); (Karyawanto, 2018)). Adapun tahapan dalam pembuatan aransemen sederhana untuk musik sekolah diantaranya adalah: (1) Menentukan lagu yang akan di aransemen; (2) Mengolah pola ritme/harga nada/irama/durasi notasi; (3) Menentukan akur; (4) Menulis melodi; (5) Progresi akur (pergerakan akur); (6) Lintas sukat. Format instrumen yang akan diaransemen menyesuaikan dengan alat musik yang dimiliki sekolah sehingga format instrumen bisa berupa kuartet, kuintet atau ansambel.

Leon Stein dalam Structure and Style menjelaskan tentang kontrapung, yaitu cara membuat bentuk-bentuk invention serta aturanaturan yang dipakai dalam membuat bentuk kontrapung sehingga sangat mendukung peneliti maupun mahasiswa dalam membuat aransemen.
Buku ini juga digunakan penulis sebagai buku tambahan pembelajaran Ilmu Harmoni (Stein, 1962).

2. Landasan Teori

Teori yang melandasi penelitian ini yaitu teori kreativitas yang dikemukakan Alma Hawkins. Menurut Hawkins, proses perancangan membutuhkan suatu kreativitas yang kemudian dikembangakan. Pengembangan kreativitas oleh mengungkapkan bahwa kondisi yang diperlukan bagi kreativitas adalah lingkungan yang memungkinkan seseorang untuk menemukan dan mengeksplorasi respon-respon uniknya, dan dorongan kearah kreativitas harus dipelihara dengan cara yang khas (Hawkins, 1991). Pelepasan dan perkembangan kreativitas dapat dianalogikan dari pemecahan masalah yang ringan tentang binatang yang ketakutan keluar dari lubang yang dalam, yang mana tuntutan dan dorongan tidak dapat terjadi begitu saja. Tiada seorangpun pencipta dapat didesak atau didorong, kreativitas memperkuat seperti dirinya yang siap untuk mencipta (Silalahi, 2017).

Hawkins mengembangkan sebuah konsep yang berhubungan dengan proses kreatif. Hawkins mengemukakan bahwa "creativity implies imaginative thought: sensing, feeling, imaging, and searching for truth" (Silalahi, 2017). Dengan melihat konsep proses kreatif tersebut maka penulis menerapkan apa yang ada dalam konsep-konsep tersebut diatas dengan perancangan seni pembuatan aransemen yang sedang dilakukan oleh penulis.

Dalam penelitian ini peneliti ingin mengembangkan ilmu yang sudah ada yaitu ilmu harmoni, ilmu tentang akur pengembangan yang dimaksud adalah dalam pembuatan aransemen dalam tangga nada yang tidak biasanya digunakan. Tujuannya adalah untuk menghasilkan produk aransemen yang baru disertai dengan bertambahnya ilmu dalam aransemen lagu yang mengacu pada ilmu harmoni klasik, karena ilmu harmoni klasik merupakan modal awal pengetahuan aransemen musik.

Strategi yang diambil peneliti dalam penelitian saat ini adalah pengamatan yang 
berupa observasi lapangan yang sudah dilakukan sebelum wabah covid, studi literatur yang mendukung dalam penelitian ini. Perencanaan dalam perancangan pembuatan aransemen melihat kemampuan dari peserta sanggar untuk menentukan hasil dari perancangan aransmenen. Peneliti juga mempunyai keinginan untuk membuat perancangan aransemen semenarik mungkin mengacu pada ilmu harmoni. Pola iringan dan ritmis sangat berpengaruh pada aransemen lagu, maka dari itu peneliti ingin membuat pola iringan berbeda dari sebelumnya. Untuk perpindahan lagu dari satu lagu ke lagu lainnya maka digunakan jembatan dengan pola iringan yang berbeda dengan pola iringan sebelumnya.

State of the art pada penelitian ini mengacu pada perkembangan yang sangat pesat penelitian mengenai teknik aransemen sudah banyak dilakukan oleh peneliti diluar ISI Yogyakarta. Akan tetapi penelitian mengenai ilmu harmoni sebagai ide perancangan aransemen belumlah ada karena hal ini berhubungan erat dengan matakuliah yang ada di Program Studi S-1 Seni Musik ISI Yogyakarta. Hasil dari penelitian ini akan sangat bermanfaat bagi mahasiswa dikarenakan akan adanya contoh teknik aransemen dasar yang sangat berhubungan dengan matakuliah yang ada. Penelitian ini bukan merupakan duplikasi dan plagiarisme ide dan sumber-sumber data akan menggunakan lebih banyak jurnal-jurnal yang relevan dengan topik penelitian.

\section{Hasil dan Pembahasan}

Hasil yang dicapai adalah aransemen lagu Suwe Ora Jamu dan Cublak-cublak Suweng, (medley) dalam bentuk ansambel yang dimainkan oleh instrumen piano atau keyboard, gitar, biola, dan vokal. The Liang Gie (1982-159) dalam (Widiyono, 2013) mengatakan bahwa sesuatu yang menimbulkan niat (interest) sesuatu yang lebih disukai (preference), kepuasan (statisfaction), kenikmatan (enjoyment), keinginan (desire). Dalam pembuatan perancangan ini memerlukan konsep yang matang dengan menitikberatkan kemampuan anak-anak dalam permainan instrumen. Pemberian akur-akur harmoni dasar seperti akur pokok menjadikan hasil aransemen permainan tidak dirasa sulit. Filler yang ada juga dibuat tidak menyusahkan anak dalam permainan musiknya dan diharapkan anak-anak menyukai karya aransemen ini.

Pada saat aransemen ini selesai menjadi sebuah karya komposisi musik dengan bentuk medley tanpa mengubah pola lagu awal, maka merupakan suatu kepuasaan tersendiri jika anak-anak sanggar memainkannya dengan senang tanpa beban. Sebelum masuk dalam perancangan aransemen maka terlebih dahulu harus mengerti mengenai unsur-unsur pokok dari musik itu sendiri (Salim, 2009). Unsur-unsur tersebut adalah: (1) Harmoni adalah bunyi gabungan dua nada atau lebih, yang tingginya berbeda dan didengar serentak atau serangkaian nada yang tersusun vertikal; (2) Irama/tempo adalah urutan rangkainan dari gerak yang menjadi unsur dasar dalam musik dan tari; (3) Melodi adalah susunan rangkaian nada yang horisontal dan terdengar berurutan serta berirama dan mengungkapkan suatu gagasan. Sensasi yang didengar dari sebuah melodi merupakan persepsi dari pitch dan ritme; (4) Bentuk atau sruktur lagu. Dalam harmoni sendiri terdapat beberapa penyusunan akur-akur seperti: contrary Motion, pararel motion, dan oblique motion. Penerapannya dalam aransemen lagu daerah ini pada instrumen pengiring baik keyboard maupun gitar. Berikut adalah hasil Aransemen Suwe Ora Jamu dan Cublak-cublak Suweng.

\section{Tahapan Perancangan Aransemen}

Perancangan aransemen ini mengacu pada Alma Hawkins. Menurut Hawkins proses penciptaan terdiri dari rangkaian tahap yaitu: (1) Eksplorasi, yang meliputi: (a) Menentukan judul/ tema/topik ciptaan melalui cerita, konsepsi; (b) Berfikir, berimajinasi, merasakan, menanggapi dan menafsirkan tentang tema yang dipilih; (2) Improvisasi, yang meliputi: (a) Percobaan-percobaan memilih, membedakan, mempertimbangkan, membuat harmonisasi, dan kontras-kontras tertentu; (b) Menentukan intergasi dan kesatuan terhadap berbagai percobaan yang telah dilakukan; 
(3) Pembentukan, yang meliputi: (a) Menentukan bentuk ciptaan dengan menggabungkan simbolsimbol yang dihasilkan dari berbagai percobaan yang telah dilakukan; (b) Menentukan kesatuan dengan parameter yang lain, seperti gerakan dengan iringan, busana dan warna; (c) Pemberian bobot seni (kerumitan, kesederhanaan dan intensitas) dan bobot keagamaan (Susanti, 2015).

Dari ketiga proses tersebut sangat erat hubungannya dengan perancangan aransemen yang sedang dilaksanan dan dapat dijabarkan sebagai berikut: (1) Eksplorasi: Dalam pembuatan aransemen untuk anak-anak maka yang muncul pertamakali adalah sejauh mana kemampuan anakanak sanggar tersebut dalam memainkan instrumen musik. Untuk mengetahui kemapuan anak-anak maka sebelumnya harus dilakukan observasi terlebih dahulu dengan terjun langsung sebagai
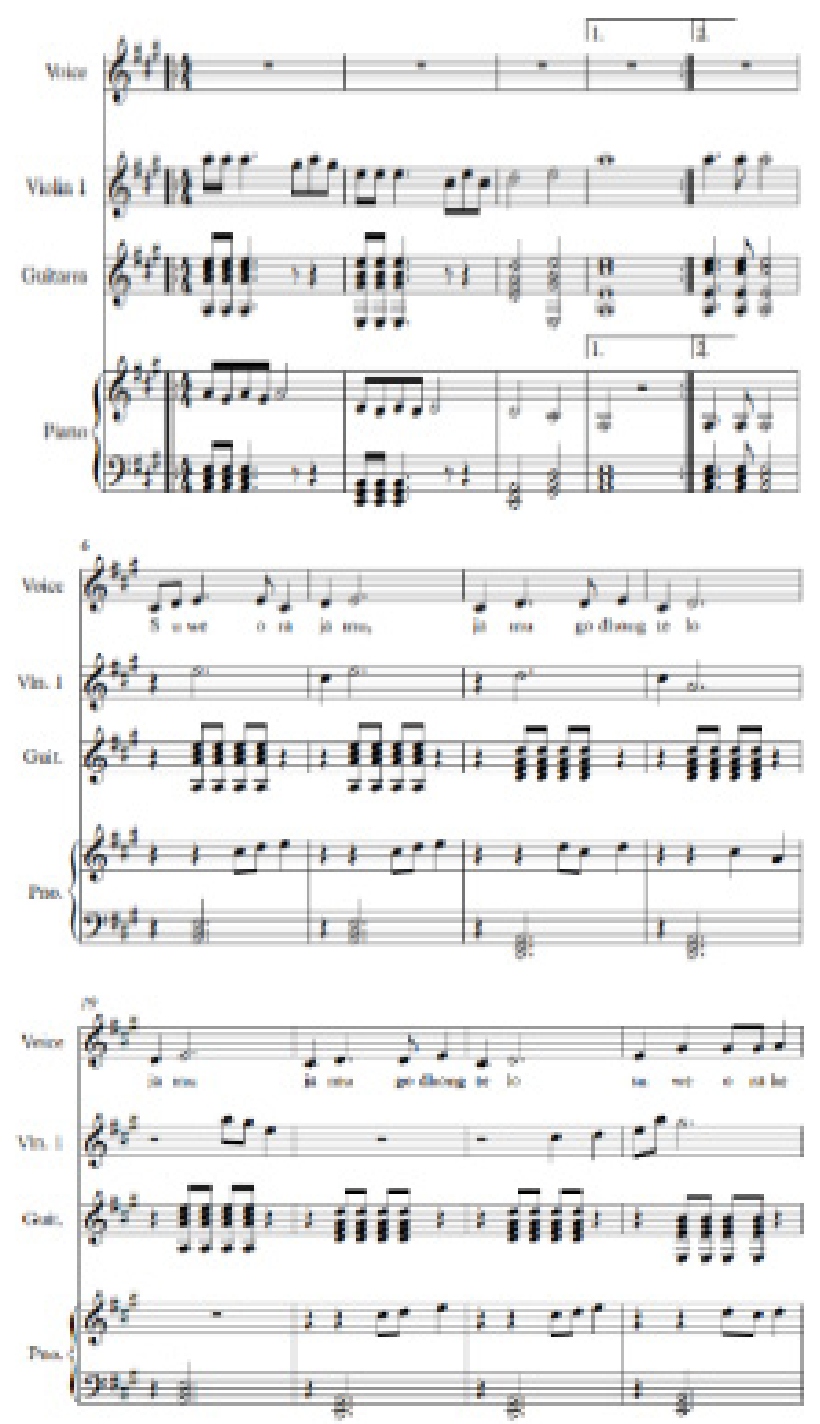

Notasi 1: Aransemen medley Suwe Ora Jamu dan Cublak-cublak Suweng. pengajar disana. Setelah diketahui kemampuan anak-anak maka kemudian menentukan jenis musik yang sekiranya mudah diterima anak-anak. Dalam pembuatan aransemen ini diharapkan anakanak bahagia dan menikmati proses latihan sampai dengan pementasan; (2) Improvisasi: Improvisasi dalam pembuatan aransemen dilakukan untuk memperindah lagu aslinya. Susunan harmoni yang sedianya hanya menggunakan akur dalam posisi dasar bisa dibuat dalam pembalikan baik satu, dua maupun tiga. Dalam pembuatan nada dasar juga harus dipertimbangkan dengan kemapuan anak dalam memainkan instrumen, maka dari itu peneliti memakai tangga nada A mayor sehingga seperti instrumen biola, gitar dan lain sebagainya tidak mengalami kesulitan. Bentuk arasemen medley dimana kedua lagu dimainkan secara berurutan, dalam aransemen ini lagu pertama
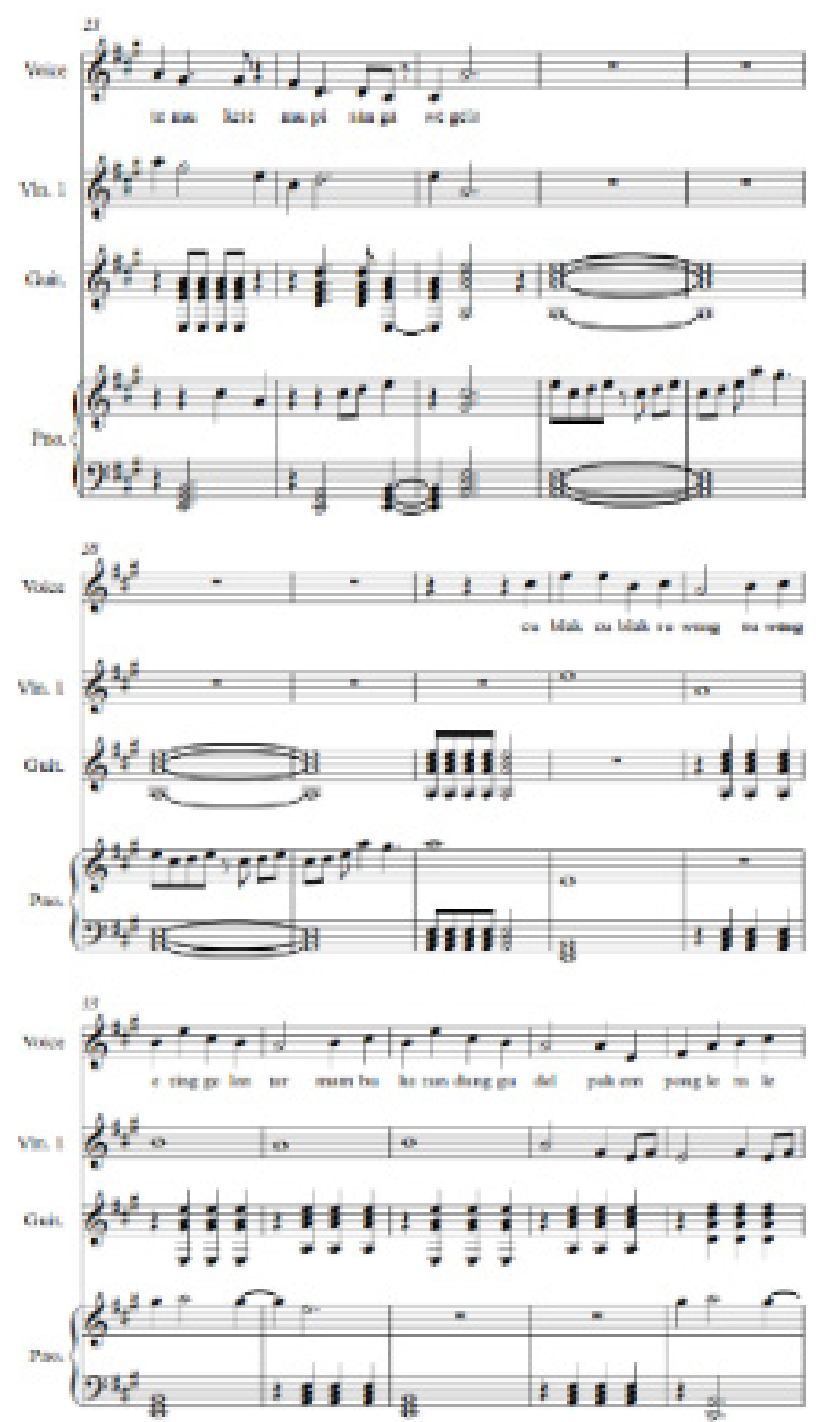
yaitu Suwe Ora Jamu kemudian Cublak-Cublak Suweng. Jika dihubungkan dengan penciptaan Hawkins maka lagu yang dipilih adalah lagu yang mudah diterima dan sering didengarkan anak-anak. Harmonisasi yang dibuat berdasarkan kemampuan dari anak itu sendiri dan dilakukan observasi dan percobaan permainan musik dengan beberapa potongan frase-frase sebelum memainkan full score.

Penyesuaian aransemen dilakukan dengan menggunakan notasi angka, khususnya pada saat melatih anak-anak sanggar. Ini merupakan penggunaan simbol-simbol yang berbeda dengan notasi balok. Hal tersebut dilakukan untuk mempermudah pembelajaran untuk anak sanggar. Hasil aransemen menggunakan iringan yang sangat sederhana dengan harmonisasi yang sederhana pula. Bentuk-bentuk kreativitas yang dilakukan oleh mahasiswa dalam aransemen adalah menentukan lagu yang akan diaransemen, bentuk dari aransemen itu sendiri dalam aransemen ini adalah medley, menentukan progresi akur yaitu dengan menggunakan akur pokok, pencapaian nilai artistik, dan penentuan tempo, tangga nada dan dinamik (Nurharini \& Sutikno, 2017).

Penggunaan akur dalam Lagu Cublak-Cublak Suweng dan Suwe Ora Jamu berada dalam tangga nada A Mayor. Terdiri dari 24 birama, intro terdiri dari 9 birama didalamnya dan terdapat pengulangan. Intro dimainkan oleh instrumen biola, gitar dan piano sedangkan vokal istirahat. Akur harmoni yang digunakan adalah I-IV-V-I, yakni akur pokok dalam posisi dasar ((Anglade et al., 2009); (Toch, 1977)).

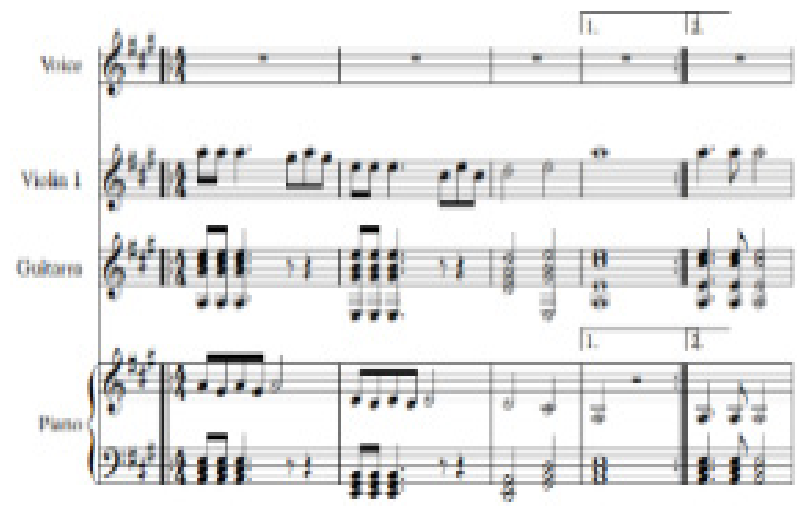

Notasi 2: Bagian introduksi.

Melodi intro dimainkan oleh instrumen biola, instrumen gitar memainkan akur I-V-IV, V-I, sedangkan instrumen piano tngan kanan memainkan melodi sedangkan tangan kiri memainkan akur I-V-IV-V-I. Susunan akur yang digunakan hanya merupakan akur pokok saja dan dengan posisi dasar dengan tujuan memudahkan anak-anak untuk memainkannnya. Akan tetapi apabila dimainkan bersamaan dengan melodi intro yang dimainkan biola, harmonisasinya (pecahan nada dalam akur-akur) akan muncul yaitu nuansa musik tradisional Jawa. Dalam Suwe Ora Jamu menggunakan tangga nada pelog.

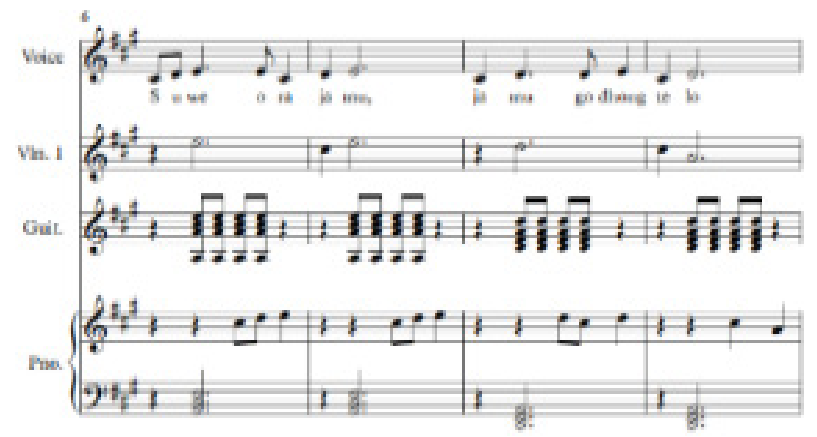

Notasi 3: Tema lagu/frase tanya.

Tema lagu dimulai dari birama 6 , dimulai dengan akur I. Melodi dimainkan oleh vokal, Instrumen gitar dan piano tangan kiri memainkan broken chord. Akur yang digunakan adalah birama 6 dan 7 akur I dalam posisi dasar, birama 8 dan 9 akur IV dalam posisi dasar. Instrumen piano pada tangan kiri memainkan akur yang sama. Dapat dikatakan bahwa dalam birama 6-9 merupakan frase tanya dikarenakan berakhir di akur IV.

Pada birama 10-13 terdapat frase jawab dimana susunan akurnya adalah V-V-IV-V-I. Dalam birama 12-13 terdapat variasi ritmis sehingga berbeda dengan frase tanya.
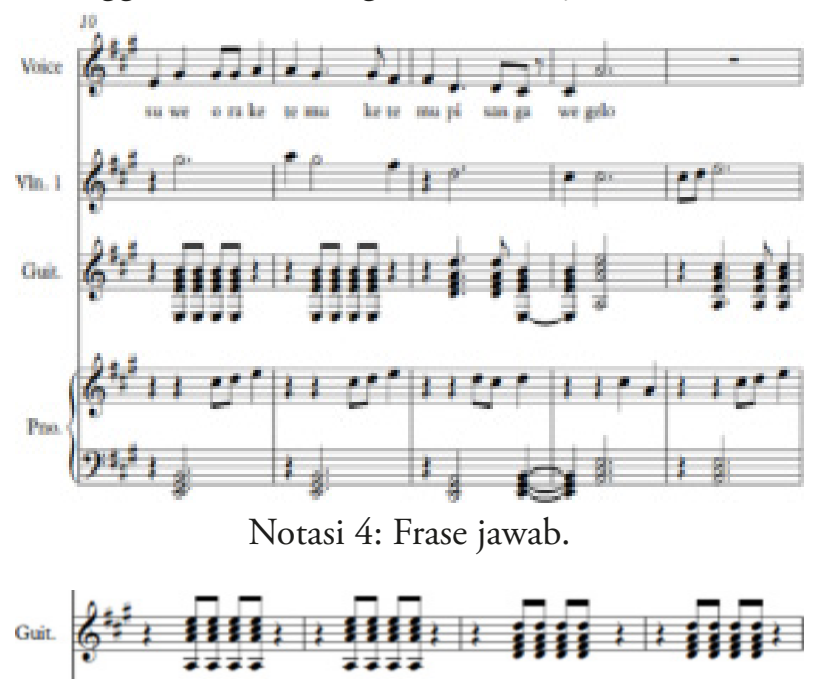

Notasi 5: Ritmis dari bagian frase tanya. 
Pada birama 14-17 terdapat pasase untuk menuju tema awal. Dalam bagian ini instrumen gitar memainkan akur I-IV-V-I, instrumen biola memainkan melodi bernuansa tangga nada pelog dan instrumen keyboard tangan kanan memainkan melodi dan tangan kiri memainkan akur sama seperti instrumen gitar, akan tetapi dalam ritmis yang berbeda.

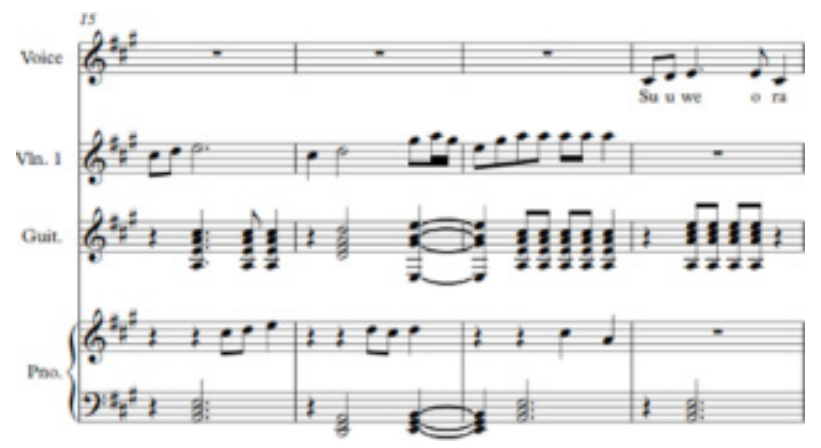

Notasi 6: Pasase menuju tema awal.

Pengulangan tema awal ini terdapat perbedaan dalam beberapa birama baik dalam ritmis iringan maupun fillernya akan tetapi susunan akurnya sama. Dibawah ini terdapat susunan akur dalam tangga nada A mayor (Strube, 1928).

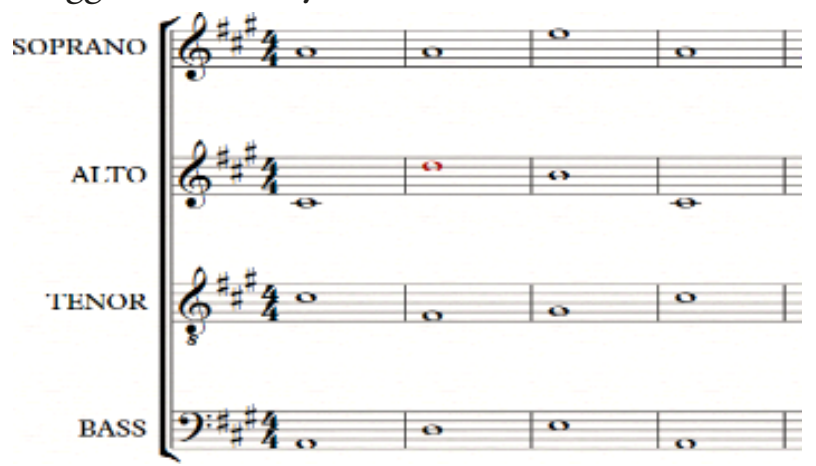

Notasi 7: Akur A Mayor posisi dasar.

Tema lagu Cublak-cublak Suweng diawali dengan up-beat melodi yang dibawakan oleh vokal. Instrumen keyboard memainkan akur $\mathrm{V}$ pada tangan kiri. Sementara tangan kanan instrumen keyboard memainkan not E bersama dengan instrumen biola. Lagu Cublak-Cublak Suweng terdiri dari 14 birama yang kemudian terdapat bridge sepanjang 8 birama serta terdapat pengulangan.

Akur A mayor (A-C\#-E) digunakan sepanjang tiga birama kemudian akur E minor (E-G\#-B)

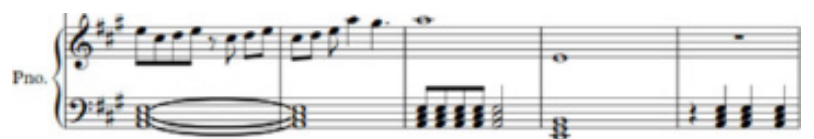

Notasi 8: Bagian bridge dan tema lagu. sepanjang 1 birama dan yang terakhir adalah akur A mayor. Akur tersebut sangat mudah dimainkan oleh anak-anak, dan semuanya dalam posisi dasar. Pada saat akur A Mayor terjadi augmentasi selama dua birama maka melodi mengambil dari tangga nada pelog, harmonisasi antara keduanya menjadi lebih indah muncul dari ide-ide kreativitas arranger.

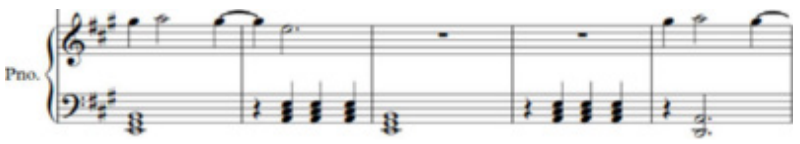

Notasi 9: Birama 38 - 42.

Akur yang digunakan masih sama yaitu $\mathrm{E}$ mayor - A mayor - E mayor - A mayor (V-I-V-I) dan birama terakhir hanya terdapat dua nada yaitu nada $\mathrm{D}$ dan A yang dibunyikan bersamaan (Anglade et al., 2009).

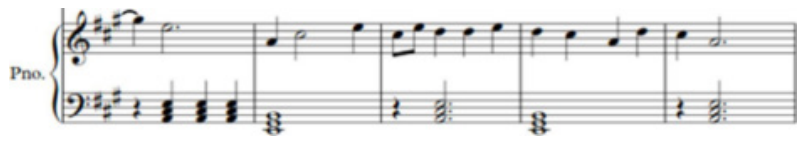

Notasi 10: Birama 38 - 42.

Di bagian ini instrumen keyboard pada tangan kanan memainkan melodi bersamaan dengan vokal tetapi berbeda dalam notasinya. Hal tersebut menjadikan aransemen ini menjadi hidup dan berkarakter, variasi tersebut menjadikan harmonisasi yang indah.

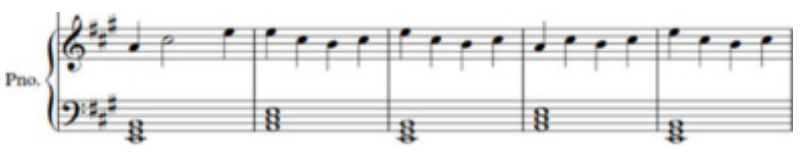

Notasi 11: Birama 43 - 47.

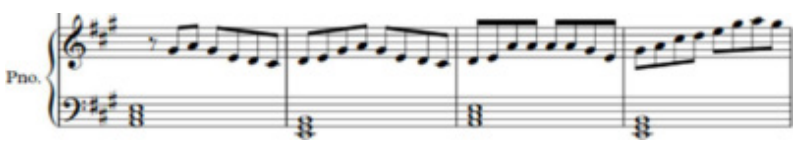

Notasi 12: Birama 48 - 51.

Pada birama 43 - 51 menggunakan akur I dan V. Terdapat melodi tangga nada yang diselaraskan dengan akur-akur.

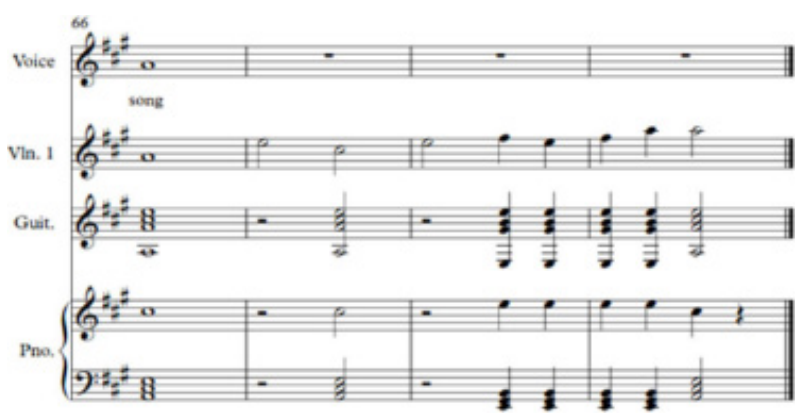

Notasi 13: Birama 66 - 69 (coda). 
Bagian coda memiliki durasi sebanyak 4 birama yang diawali dengan akur I (A mayor) dan diakhiri dengan akur V (E mayor). Instrumen gitar dan keyboard tangan kiri memainkan broken chord sedangkan biola dan keyboard tangan kanan memainkan melodi tangga nada.

\section{Proses Pelatihan}

Pelatihan hasil aransemen Suwe Ora Jamu dan Cublak-cublak Suweng melibatkan anggota peneliti yaitu mahasiswa Program Studi S-1 Seni Musik FSP ISI Yogyakarta. Namun dalam pelaksanaannya, proses pelatihan turut melibatkan para pengajar yang di bertiugas di Sanggar Seni Notoyudan, Yogyakarta. Proses pelatihan yang dilakuakn berorientasi pada permainan, bukanlah capaian estetis semata. Ini mengacu pada pernyataan Rosmiati yang menjelaskan bahwa anak-anak dapat merasakan musik sebagai aktivitas dalam bermain (Rosmiati, 2014). Dengan demikian, proses pelatihan dilakukan dengan membangun suasanan yang menyenagkan dan berorientasi pada permainan.

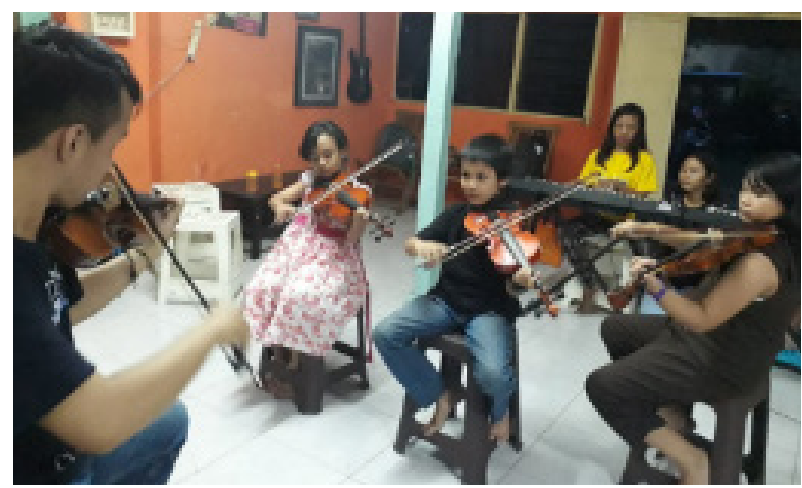

Gambar 1: Pelatihan instrumen musik oleh anggota peneliti mahasiswa.

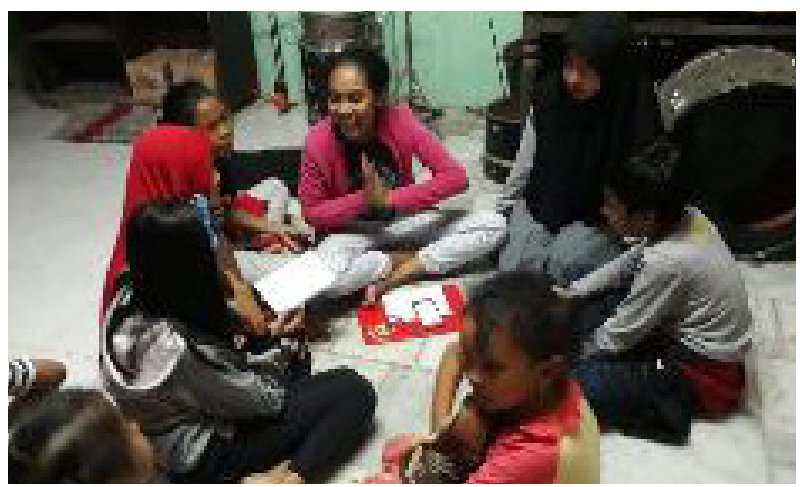

Gambar 2: Pelatihan vokal oleh anggota peneliti mahasiswa.
Pembuatan arasemen untuk disesuaikan dengan kemampuan anak-anak sanggar. Masingmasing anak mempunyai instrumen biola sehingga ketika berada dirumah mereka dapat berlatih mandiri, sehingga pada waktu berlatih di sanggar mereka sudah sedikit-sedikit bisa walaupun suara yang dihasilkan masih belum memenuhi standar. Guru tetap dari sanggar tersebut adalah Bapak Tembong. Ia adalah lulusan dari Universitas Negeri Yogyakarta. Selain mengajar di sanggar tersebut beliau juga aktif konser di berbagai pertunjukan.

Dokumentasi menunjukkan proses latihan yaitu pelatihan olah vokal bagi anak-anak sanggar yang dilakukan oleh anggota peneliti mahasiswa. Dalam latihan ini, peneliti tidak menemukan kendala berarti dikarenakan lagu yang dipilih sudah familiar bagi anak-anak sanggar. Suara vokal tidak dipecah menjadi empat suara SopranAlto-Tenor-Bass (SATB) dikarenakan melihat dari kemampuan anak-anak sanggar, sehingga vokal hanya membawakan satu suara. Usia dari anak-anak sanggar bervariasi, dan juga kualitas vokal berbeda-beda. Mahasiswa sebagai pelatih diharapkan sabar dalam membimbing anak-anak

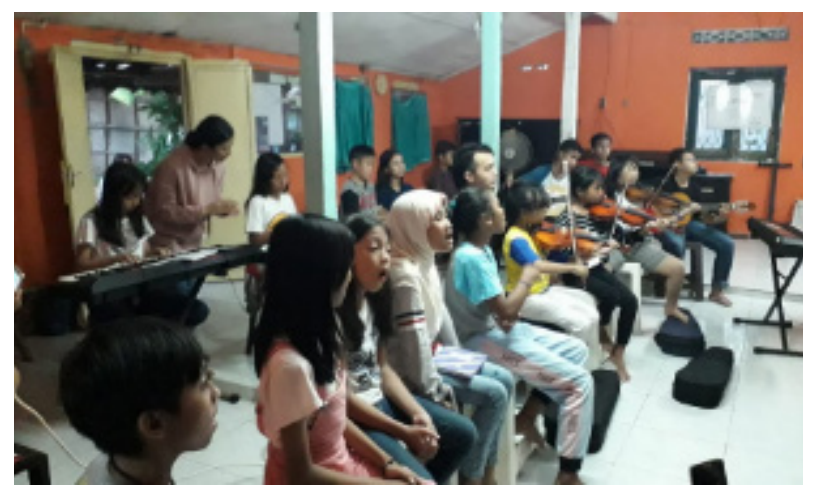

Gambar 3: Latihan gabungan instrumen dan vokal.

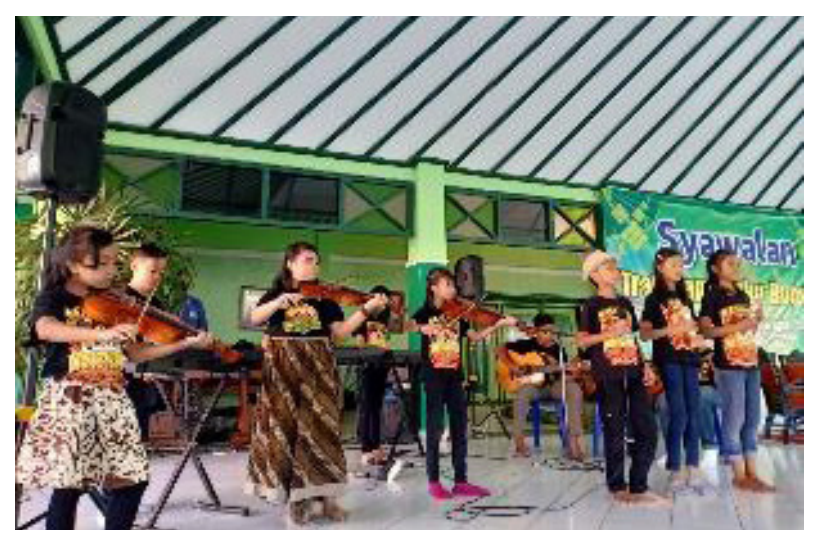

Gambar 4: Pementasan Suwe Ora Jamu dan Cublakcublak Suweng. 
dan harus diselingi tawa canda sehingga mereka tidak merasa bosan. Kegiatan bernyanyi menurut adalah kegiatan yang menyenangkan bagi peserta dan pengalaman bernyanyi ini memberikan kepuasan kepadanya selain itu adalah merupakan alat bagi peserta untuk mengungkapkan pikiran dan perasaannya (Sihombing, n.d.).

Kedua lagu daerah/tradisonal yang dibawakan anak-anak sanggar mencerminkan suatu permainan anak, sehingga dalam membawakan lagu ini anak-anak terbawa suasana bahagia. Lagu daerah mempunyai karakter dan ciri tersendiri, bahasa dan gaya lagu yang digunakan sama dengan asal usul dari daerahnya (Setiowati, 2020). Kedua lagu yang diaransemen disini merupakan lagu dolanan anak. Menurut Endraswara (2005) membagi kategori lagu dolanan anak di jawa yaitu: (1) Proto Folksong; (2) Lagu Nina Bobo (lullaby); (3) Lagu permainan (playing song) dan lain sebagainya (Setiowati, 2020).

Lagu anak-anak mempunyai karateristik musikal tersendiri yaitu 1) Melodi mudah diingat dan menarik untuk dinyanyikan walaupun tanpa kata-kata; 2) Irama dalam nyanyiannya tegas dan mudah diingat; 3) Liriknya selaras dengan alur melodi; 4) Pesan dan perasaan isi lirik sesuai dengan karakter musik; 5) Lirik dapat bersifat sebagai hiburan, permainan ataupun pratiotis, akan tetapi tidak diajarkan secara tertulis; f. Ambitus menyenangkan/menarik untuk dinyanyikan oleh semua suara anak (Tyasrinestu, 2014).

Latihan gabungan dilakukan pada saat para pemain instrumen telah mencapai kesiapan dalam memainkan bagian masing-masing. Permasalahan yang timbul adalah mengenai tempo yang berbeda satu dengan yang lain hingga terkesan kerjarkejaran, akan tetapi semua itu dapat teratasi dengan baik.

\section{Kesimpulan}

Konsep perancangan aransemen lagu Suwe Ora Jamu dan Cublak-cublak Suweng muncul pada saat peneliti menjadi pembimbing PKL di Program Studi S-1 Seni Musik FSP ISI Yogyakarta. Didukung dengan latar belakang pengajar Ilmu Harmoni maka muncul suatu ide perancangan pengolahan aransemen melalui ilmu harmoni dengan aplikasinya yaitu variasi-variasi akur. Kedua lagu tersebut menggunakan tangga nada pentatonis akan tetapi penulisan dalam aransemen ini menggunakan notasi balok. Instrumen yang digunakan menggunakan instrumen seperti instrumen biola, keyboard, gitar dan vokal. Dengan adanya perbedaan tangga nada tidak menyulitkan penulis untuk membuat aransemen, karena tangga nada diatonis dapat diselaraskan dengan tangga nada pentatonis.

Adapun kesimpulan yang dapat diambil yaitu proses perancangan aransemen dilakukan secara bertahap meliputi beberapa aspek, yaitu: (1) Instrumen yang digunakan; (2) Tingkat kemapuan anak; (3) Pemilihan tangga nada. Tangga nada yang sangat mudah dimainkan oleh semua instrumen termasuk vokal; (4) Proses pembuatan menggunakan tangga nada AM dengan akur-akur pokok seperti I-IV-V dan dalam posisi dasar, peletakan akur-akur dibuat variasi sehingga menghasilkan nuansa tangga nada pentatonis; (5) Kreativitas dalam pembuatan aransemen seperti membuat filler, introduksi, bridge, dan coda; (6) Menggunakan melodi bernuanasa tradisional Jawa untuk memperkuat kesan lagu daerah; (7) Tempo menyesuaikan kecepatan dan keterampilan para pemain; (8) Notasi yang digunakan merupakan kelompok sederhana.

Dalam konteks ilmu harmoni sebagai unsur ide perancangan aransemen lagu Suwe Ora Jamu dan Cublak-cublak Suweng, dalam pembuatan aransemen tidak mengalami perbedaan dalam penyusunan harmonisasinya walaupun menggunakan tangga nada pentatonis. Untuk menghasilkan nuansa pentatonis maka dalam pembuatan filler-filler menggunakan melodi tangga nada pentatonis.

\section{Kepustakaan}

Anglade, A., Ramirez, R., \& Dixon, S. (2009). Genre Classification Using Harmony Rules Induced from Automatic Chord Transcriptions. Ismir, 669-674.

Ceunfin, F., Kian, M., \& Tukan, M. K. A. (2019). Analisa Unsur Musikal Go Laba Musik 
Tradisional Ngada Sebagai Iringan Tarian Ja’i Pada Sanggar Mora Masa Kel. Tuak Daun Merah (TDM 02) Kec. Oebobo-Kupang. Ekspresi Seni: Jurnal Ilmu Pengetahuan Dan Karya Seni, 21(1), 30.

Gunawan, I. (2013). Metode penelitian kualitatif. Jakarta: Bumi Aksara, 143.

Hasibuan, H., Djau, N. S., \& Muniir, A. (n.d.). Melodious: Karya Musik Absolut. Jurnal Pendidikan Dan Pembelajaran Khatulistiwa, $8(10)$.

Hawkins, A. M. (1991). Moving from within: A new method for dance making. Eric.

Karyawanto, H. Y. (2018). Bentuk Lagu dan Ambitus Nada Pada Orkestrasi Mars Unesa. Virtuoso (Jurnal Pengkajian Dan Penciptaan Musik), 1(1), 8-14.

Kusumawati, H. (2016). Kreativitas Dalam Pembuatan Aransemen Musik Sekolah. Imaji: Jurnal Seni Dan Pendidikan Seni, 14(1), 5764.

Mulyani, S. (2017). Metode Analisis dan Perancangan Sistem. Abdi Sistematika.

Nurharini, A., \& Sutikno, P. Y. (2017). Metode Image Streaming dalam Meningkatkan Kreativitas Aransemen Musik. Jurnal Kreatif: Jurnal Kependidikan Dasar, 7(2).

Pardede, M. M. J., \& Purba, B. A. (2021). Strategi Pembelajaran Tangga Nada Pada Siswa Kelas X SMTK Kristo Manado. Jurnal Psalmoz, 2(1), 89-99.

Prier, K.-E. (1996). Ilmu Bentuk Musik (p. 42). Pusat Musik Liturgi.

Rochani, S. (2012). Lagu Daerah. PT Balai Pustaka (Persero).

Rosmiati, A. (2014). Teknik stimulasi dalam pendidikan karakter anak usia dini melalui lirik lagu dolanan. Resital: Jurnal Seni Pertunjukan (Journal of Performing Arts), 15(1), 71-82.

Rumengan, P. (2009). Musik Gerejawi Kontekstual Etnik. In Jakarta: Panitia Pelaksana Kongres Kebudayaan Minahasa.
Salim, D. (2009). Psikologi musik. Yogyakarta: Best Publisher.

Sanjaya, R. M. S. (2013). Metode Lima Langkah Aransemen Musik. Promusika: Jurnal Pengkajian, Penyajian, Dan Penciptaan Musik, 1(1), 33-49.

Scholes, P. A. (1983). The New Oxford Companion to Music (Vol. 1). Oxford; New York: Oxford University Press.

Setiowati, S. P. (2020). Pembentukan Karakter Anak Pada Lagu Tokecang, Jawa Barat. Jurnal Ilmu Budaya, 8(1), 172-177.

Sihombing, L. B. (N.d.). Metode Bernyanyi Kategori Lagu Folklore/Etnik Dalam Paduan Suara. Generasi Kampus, 7(2).

Silalahi, M. L. (2017). Pengembangan Kreativitas dan Inovasi Penciptaan Karya Tari dengan Metode Laboratorium Tari (Studi Kasus: Yayasan Seni Duta Santarina Batam). Imaji: Jurnal Seni Dan Pendidikan Seni, 15(2), 189-196.

Stein, L. (1962). Structure and style: the study and analysis of musical forms. Summy-Birchard Company.

Strube, G. (1928). The Theory and Use of Chords: A Text-Book of Harmony. Oliver Ditson Company.

Susanti, D. (2015). Penerapan Metode Penciptaan Alma Hawkins Dalam Karya Tari Gundah Kancah. Ekspresi Seni: Jurnal Ilmu Pengetahuan Dan Karya Seni, 17(1), 41-56.

Toch, E. (1977). The shaping forces in music: an inquiry into the nature of harmony, melody, counterpoint, form. Courier Corporation.

Tyasrinestu, F. (2014). Lirik Musikal pada Lagu Anak Berbahasa Indonesia. Resital: Jurnal Seni Pertunjukan (Journal of Performing Arts), 15(2), 163-168.

Widiyono, Y. (2013). Nilai Pendidikan Karakter Tembang Campursari Karya Manthous. Jurnal Pendidikan Karakter, 2(2).

Yaumi, M. (2016). Action Research: Teori, model dan aplikasinya. Prenada Media. 